\title{
Impacts of detrital enrichment on estuarine assemblages: disentangling effects of frequency and intensity of disturbance
}

\author{
Melanie J. Bishop*, Brendan P. Kelaher \\ Department of Environmental Sciences and Institute for Water and Environmental Resource Management, \\ University of Technology Sydney, PO Box 123, Broadway, New South Wales 2007, Australia
}

\begin{abstract}
Under climate change, enhanced storminess may increase the magnitude and rate of detrital loading to the benthos, potentially altering sediment chemistry and/or physical disturbance of sediments. To assess whether the impact of detrital loading on invertebrates in intertidal sediment sparsely vegetated by seagrass is negatively affected by increasing the frequency and/or intensity of the disturbance, high (90 $\mathrm{g}$ dry weight) or low (30 $\mathrm{g}$ dry weight) quantities of shredded Zostera capricornii were added to experimental plots at high (intervals of $8 \mathrm{wk}$, on a total of 3 occasions) or low (added once) frequency. Macroinvertebrate assemblages were sampled 8, 16 and 24 wk after the first detrital enrichment. Plots subjected to frequent detrital addition contained up to $50 \%$ fewer macroinvertebrates, representing $50 \%$ fewer taxa than plots disturbed only once. This pattern was independent of disturbance intensity and emerged after only 2 detrital additions. Only at the low frequency of addition did the increased quantity of detritus influence macroinvertebrate assemblage composition, halving the number of animals by Week 24. Physical disturbance, not sediment chemistry, drove the frequency effect. Generally negative impacts of frequent detrital enrichment on infaunal populations occurred despite small positive effects of high detrital enrichment on the biomass of microphytobenthos, the food source of many sediment-dwelling invertebrates. These results suggest that, even though climate warming may increase the amount of detritus that is washed up onto intertidal sediments, its greater effect on soft-sediment communities is likely to come through increasing the frequency of storms.
\end{abstract}

KEY WORDS: Detrital enrichment $\cdot$ Frequency $\cdot$ Intensity $\cdot$ Macroinvertebrate $\cdot$ Zostera capricornii

\section{INTRODUCTION}

Disturbances, discrete events in time that disrupt ecosystems (Pickett \& White 1985), are important determinants of diversity (e.g. Connell 1978, Huston 1994). In causing mortality within populations, disturbances free resources and facilitate new colonisation, resulting in changes to assemblages that are dependent on their frequency, intensity and scale (e.g. Sousa 1985, Huston 1994). Because the frequency, intensity and scale of disturbances are often confounded in natural ecosystems, the relative importance of these 3 parameters in determining ecological community dynamics is, however, difficult to disentangle (Benedetti-Cecchi 2003). Although moderate disturbances that leave a residual assemblage occur relatively frequently in natural systems, disturbances that scour the landscape are relatively rare. Thus, most studies examining the effect of disturbance regime on ecological structure consider recovery sequences between regularly spaced disturbances of low intensity or small scale, or follow single disturbances of high intensity or large scale (e.g. Pickett \& White 1985, Sousa 1985, Paine et al. 1998). Increasingly, however, human enterprises such as agriculture, industry, recreation and international commerce are increasing the frequency 
at which disturbances of high intensity and/or large scale occur (Paine et al. 1998, Sala et al. 2000).

Over the next $100 \mathrm{yr}$, the globally averaged surface temperature is projected to increase by 1.4 to $5.8^{\circ} \mathrm{C}$, depending on different scenarios of future emission trends and climate models used (IPCC 2001). Global climate change is likely to increase the frequency and intensity of extreme events such as storms, droughts, fires and heat waves (IPCC 2001). Storms alter the timing, amount and quantity of nutrient input to terrestrial and aquatic ecosystems and may have particularly severe effects in estuaries previously disturbed by human activities (Michener et al. 1997). Excessive precipitation can produce order of magnitude increases in riverine discharge, which can significantly alter currents and salinity regimes in downstream reaches and increase non-point sources of sediments, nutrients and organic materials (Paerl 2006). Consequently, there is a growing need for ecologists to refocus their concern from the ordinary to the extraordinary (Paine et al. 1998). Understanding the ecological consequences of increasing frequencies and intensities of disturbance are particularly critical in marine and estuarine soft sediment systems that support economically important fisheries and vital ecosystem processes such as carbon and geochemical cycling (Snelgrove 1999).

Amongst the potential consequences of enhanced storminess is an increase in the frequency and intensity with which detritus, dead organic matter, is deposited on intertidal mudflats. Increased storminess may enhance organic matter deposition by: (1) increasing the amount of organic matter entering the estuary from external sources within the watershed; (2) increasing, through the provision of limiting nutrients, the productivity of fast-growing, macro- and micro-algae that will eventually enter the detrital food web (Paerl 2006); and (3) enhancing, through algal shading and overgrowth, the senescence of longerliving macrophytes such as seagrasses (Dennsion et al. 1993, Jernakoff et al. 1996). In several United States estuaries, changes in patterns of organic matter deposition that appear to be linked to increasing storminess have already been observed (Paerl 2006).

Here, we consider the independent and interacting effects of altering the frequency and intensity of detrital addition on the population dynamics of macroinfauna. In estuarine soft-sediment systems, detritus is the major carbon pathway fuelling populations of sediment-dwelling invertebrates (Findlay \& Tenore 1982, Rublee 1982). The decay of buried detritus releases nutrients, particularly $\mathrm{N}$ and $\mathrm{P}$, and enhances the reproduction of benthic microalgae and the growth of aerobic and anaerobic bacteria (Rublee 1982, Diaz \& Yap 1999), thereby influencing the structure of macrobenthic communities, total infaunal biomass and sec- ondary production (Rhoads et al. 1978, Kelaher \& Levinton 2003). Although at low frequencies and intensities of detrital loading, macroinfaunal abundance may increase with enrichment, previous research suggests that the effects of detrital addition on benthic community structure may be non-linear, with large or frequent inputs having negative effects (Pearson \& Rosenberg 1978). Consequently, if, under climate warming, increasingly frequent and intense storms increase the magnitude or rate of detrital loading, large negative effects on macroinfauna may occur that greatly contrast effects seen at low frequencies or intensities. We tested these predictions using a fully factorial experiment, manipulating the intensity and frequency of detrital disturbance.

\section{MATERIALS AND METHODS}

Experimental manipulations and sampling. This study was done on the intertidal mudflat of Quibray Bay $\left(34^{\circ} 01^{\prime} 29^{\prime \prime} \mathrm{S}, 151^{\circ} 10^{\prime} 45^{\prime \prime} \mathrm{E}\right)$, part of the Towra Point Aquatic Reserve, Botany Bay, Sydney (see Bishop et al. 2007 for a full description). This mudflat is typical of those found along the coastline of New South Wales, Australia, and is seasonally covered by sparse, stunted Zostera capricornii Aschers (mean [ \pm 1 SE] shoot length: $18.3 \pm 4.1 \mathrm{~mm}$; mean $[ \pm 1 \mathrm{SE}]$ blade width: $1.0 \pm 0.1 \mathrm{~mm}, \mathrm{n}=20$ ) and Halophila ovalis (R.Br.) Hook.

To test the hypothesis that the frequency and intensity of detrital addition influences the structure of benthic assemblages, we established a fully factorial field experiment in November 2005. The experiment had 2 factors, intensity and frequency of disturbance, each of which had 2 levels, high and low. Into the upper $3 \mathrm{~cm}$ of 42 haphazardly selected $0.25 \mathrm{~m}^{2}$ sediment plots we hand-churned $90 \mathrm{~g}$ of dried shredded Zostera capricornii (high-disturbance intensity [HI]). To an additional 42 plots, we added $30 \mathrm{~g}$ of detritus (lowdisturbance intensity [LI]) using a similar methodology. The amount of dry detritus added to high-detritus treatments was equivalent to about $400 \mathrm{~g}$ wet weight, an amount that could be reasonably deposited after a large storm (Rossi \& Underwood 2002). The low intensity of disturbance was set at one-third of the high intensity. Plots were situated at a tidal height during mean low water spring (MLWS) tide of $+0.4 \mathrm{~m}$ and were separated by a distance of at least $1.5 \mathrm{~m}$. Our detrital manipulations, like those of many previous studies (e.g. Rossi \& Underwood 2002, Kelaher \& Levinton 2003), were done on a small spatial scale, because the natural topographic features of mudflats, such as mounds and depressions, tend to produce patchiness on the scale of metres in the accumulation 
of detritus (Kelaher \& Levinton 2003). We chose to use $Z$. capricornii in our detrital manipulations because: (1) it is a major constituent of wrack in many New South Wales estuaries (e.g. Rossi \& Underwood 2002) and (2) recent observations in the Sydney area suggest that it is particularly prone to dislodgement and overgrowth following storms (Cummins et al. 2004, M. J. Bishop pers. obs.).

The Zostera capricornii used for this experiment was collected following a period of heavy rain and strong winds and had a $\mathrm{C}: \mathrm{N}$ ratio of $25.26 \pm 0.05(\mathrm{n}=3)$. The seagrass, with epiphytes still attached, was air dried outside for $2 \mathrm{wk}$, oven dried at $60^{\circ} \mathrm{C}$ for $72 \mathrm{~h}$, shredded into small pieces of $<2 \mathrm{~mm}$ and stored at $-20^{\circ} \mathrm{C}$. Seagrass was shredded to maximise its uptake into the detritus-based food web and minimise any influence of the physical structure of the seagrass blades, which can influence soft-sediment communities (Rossi \& Underwood 2002). Use of dried detritus allowed us to use material collected at a single time for each of our detrital additions, which were spread across $16 \mathrm{wk}$, thus avoiding the confounding of detrital collection and addition times. Use of dried detritus should not have significantly affected decay processes given that patterns of mass loss and chemical changes of fresh litter are frequently comparable to those of dried litter in aquatic systems (Gessner 1991). Although the physical disturbance of hand-churning detritus into the sediment may disrupt benthic assemblages, we did not attempt to separate this disturbance from the chemical disturbance of the detrital enrichment. During storms, the top few centimetres of the sediment are naturally mixed by wind and waves (e.g. Bell et al. 1997), making it unlikely that detrital enrichment would naturally occur without simultaneous mixing of the sediment. Moreover, due to the demonstration by previous studies at this and other locations (Kelaher \& Levinton 2003, Bishop et al. 2007) that the physical disturbance of a single detrital addition does not influence macroinvertebrate assemblage composition, we did not anticipate changes in macroinvertebrate assemblages to be driven by the physical disturbance.

We established high frequencies of disturbance by adding additional quantities of detritus to half of the low- and half of the high-intensity disturbance plots after 8 and 16 wk (Fig. 1). Detritus was added in the same quantities as at the start of the experiment (i.e. $90 \mathrm{~g}$ for high-intensity plots and $30 \mathrm{~g}$ for low-intensity plots). Low-frequency treatments did not receive additional detritus on either occasion (Fig. 1). By the conclusion of the experiment, the low-frequency, highintensity treatment had received the same total amount of detritus added as the high-frequency, low-intensity treatment. To discriminate between short- and long-term effects of altering the frequency and intensity of detrital additions, we sampled assemblages of macroinvertebrates and

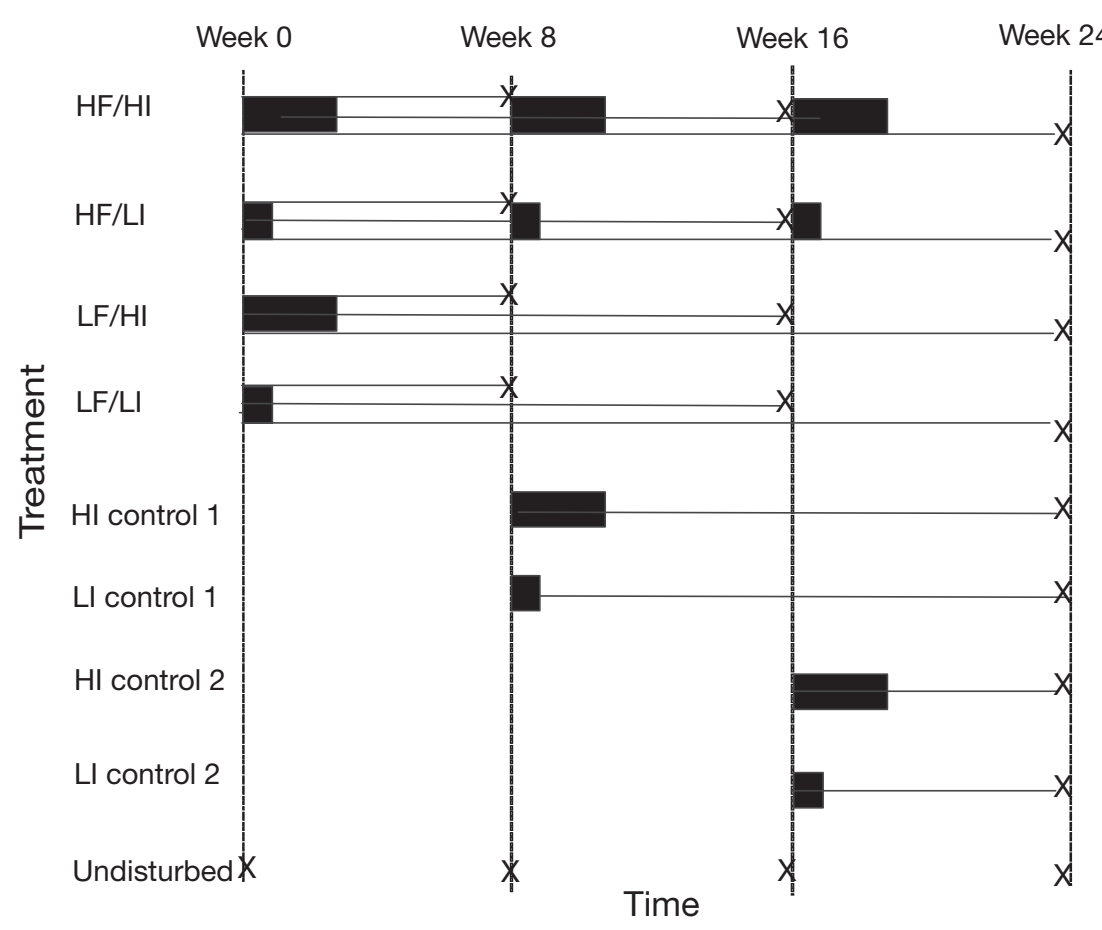

Fig. 1. Schematic of the experimental design. Black boxes denote experimental enrichment of the sediment, with the size of the box proportional to detrital loading. $X$ indicates the timing of sample collection $(n=7)$. HF: high frequency; LF: low frequency; HI: high intensity; LI: low intensity associated sediments after 8, 16 and 24 wk. Sampling at 8 and 16 wk was conducted immediately prior to the disturbance frequency. To maintain temporal independence of sampling, each plot was sampled only once, resulting in $\mathrm{n}=7$.

Because any difference in macroinvertebrate assemblages between plots disturbed at high and low frequency may be attributable to individual disturbance events at 8 or 16 wk and not necessarily the frequency of the disturbance per se, distinction of frequency effects required an additional 2 treatments in our experimental design, in which detritus was added once only, in either Week 8 or 16. In the event of an effect of disturbance frequency, we predicted that negative effects of high-frequency addition would not be replicated in any of the low-frequency treatments, irrespective of when the detritus was added. Plots with high and low quantities of addition of detritus to plots of high- 
detritus were established in each of Weeks 8 and 16 (Fig. 1). These plots, which received only a single dose of detritus, were sampled at the conclusion of the experiment in Week 24. To distinguish between effects of discrete disturbance events and the frequency of disturbance, we compared macroinvertebrate assemblages in sediment collected at the conclusion of the experiment (Week 24) between plots disturbed once in Week 0,8 , or 16 and plots disturbed on all 3 occasions.

We sampled infauna by collecting a single $15 \mathrm{~cm}$ diameter core, depressed to a depth of $8 \mathrm{~cm}$, from the centre of each plot. This size of core collects significantly more infaunal species and provides a more precise measure of diversity of macroinfaunal assemblages than cores of either 5 or $10 \mathrm{~cm}$ diameter (Bishop et al. 2007). To determine sediment carbon and nitrogen concentrations, and hence ascertain how experimental enrichment changed the local environment of macroinvertebrates, we collected 2 additional cores of sediment from each plot using a $5 \mathrm{~cm}$ diameter corer depressed to $8 \mathrm{~cm}$. Carbon/nitrogen cores were slightly shallower than infaunal cores, because we did not want to over-represent sediments below the depth of detrital addition and because most animals are found in the top few centimetres of the sediment, so, presumably, they respond to the conditions there. Infaunal samples were transported back to the laboratory, where they were sieved through a $1.0 \mathrm{~mm}$ sieve, fixed in $7 \%$ formalin solution and then transferred to $70 \%$ ethanol. Animals retained by the sieve were enumerated and, where taxonomic resources allowed, sorted to species. Although a $1.0 \mathrm{~mm}$ sieve misses small annelids and crustaceans, some of which display strong responses to organic enrichment (e.g. Junkins et al. 2006), in a previous study at this location (Bishop et al. 2007), we demonstrated that this sieve size is adequate for the detection of differences in macroinvertebrate assemblage structure between plots to which detritus is added and procedural controls. We determined the $\mathrm{C}: \mathrm{N}$ ratios of sediment samples by drying a sub-sample of each to constant weight at $70^{\circ} \mathrm{C}$, grinding dried samples to a fine powder and running $\sim 0.2 \mathrm{~g}$ of each through a CHN analyser (Leco TruSpec CN). Because few particles of detritus were distinguishable in dried sediment samples, they were not removed prior to grinding. Given the small contribution of detrital particles to the total volume of sediment samples, they are unlikely to have significantly affected the C:N ratios of the sediment. We averaged the results of the 2 $\mathrm{C}: \mathrm{N}$ analyses per experimental plot for the purposes of statistical analysis.

Any change in the abundance and/or assemblage composition of macroinvertebrates may be attributed to the physical disturbance associated with detrital enrichment and/or change in resource availability. To assess whether the effect of the disturbance on macroinfauna might be due to a reduction in stunted, though potentially habitat-providing, seagrass, we removed all seagrass tissue from each of our macroinfaunal cores and separated it into Halophila ovalis and Zostera capricornii shoots and total below-ground material. Each of the 3 components was then dried to constant weight at $70^{\circ} \mathrm{C}$ (approximately $24 \mathrm{~h}$ ) and weighed. To ascertain the effect of detrital enrichment on microphytobenthos, we measured the concentration of chlorophyll $a(\mathrm{chl} a)$, the essential photosynthetic pigment, in surface sediments of plots at each time of sampling. Using a $2 \mathrm{~cm}$ diameter corer depressed to $0.5 \mathrm{~cm}$ we collected 2 samples of surface sediments from each plot. Cores were immediately placed in a darkened cooler. Back at the laboratory, excess water was carefully removed by blotting. Dried cores were immersed in $90 \%$ acetone for $48 \mathrm{~h}$ of pigment extraction at $4{ }^{\circ} \mathrm{C}$ in darkness. The chl a concentration of the acetone solution was determined spectrophotometrically (Varian Cary 1E UV-VIS) such that: [chl a] extract $=\left(11.85 A_{664} / l\right)-\left(1.54 A_{647} / l\right)-\left(0.08 A_{630} / l\right)($ Jeffrey \& Humphrey 1975), where $A$ is the absorbance of the extract solution at the specified wavelength and $l$ is the pathlength of the cuvette in centimetres.

Although this method of microphytobenthic biomass estimation does not correct for pheopigments, we consider it suitable for determining general patterns of difference in microphytobenthic biomass among treatments (as opposed to accurate concentrations). A previous study at this site (Bishop et al. 2007) demonstrated that across experimental treatments of varying detrital enrichment, chlorophyll estimates obtained using the method by Jeffrey \& Humphrey (1975) are highly correlated with the PAM fluorescence of surface sediments, a known indicator of microphytobenthic biomass (Serodio et al. 2001). We expressed chl a concentrations per surface area of sediment.

Data analysis. We utilised a variety of multivariate and univariate techniques to assess the independent and interacting effects of the frequency and intensity of detrital addition on the population dynamics of macroinfauna. To test hypotheses about multivariate change in macroinvertebrate community structure, we used non-parametric multivariate analyses of variance (PERMANOVA: Anderson 2001) on a Bray-Curtis dissimilarity matrix (Bray \& Curtis 1957), calculated from untransformed data. PERMANOVA considers differences among assemblages in composition, richness, and/or individual species abundances to partition variance in a similar way as univariate analysis of variance. We tested hypotheses about differences in total abundance of macroinvertebrates and taxonomic richness and evenness of assemblages ( $J^{\prime}$ : Pielou 1975) with analyses of variance (ANOVA). Analogous univariate 
analyses were done on sediment carbon to nitrogen $(\mathrm{C}: \mathrm{N})$ ratios, percent $\mathrm{C}$ and percent $\mathrm{N}$, seagrass shoot and root biomasses, as well as chl $a$ and total chlorophyll concentrations. These latter analyses were to assist in identifying the mechanism of infaunal impact. Analyses had 3 orthogonal factors: time (fixed: Weeks $8,16,24)$, frequency (fixed: high, low) and intensity (fixed: high, low). The species abundance, species richness and evenness of macroinvertebrate assemblages were transformed with $\ln (x+1)$ prior to analysis to ensure assumptions of general linear models were met. $\mathrm{C}: \mathrm{N}$ ratios, percent $\mathrm{C}$ and percent $\mathrm{N}$ were arcsine transformed. ANOVAs were followed by a posteriori Student-Newman-Keuls (SNK) tests to identify those treatment means that differed significantly at $\alpha=0.05$.

To graphically show relationships among macroinvertebrate assemblages, we generated 2-dimensional ordinations of multivariate data using non-metric multidimensional scaling (NMDS: Field et al. 1982). We used SIMPER to calculate the contributions of different species to observed patterns of dissimilarity among treatments (Clarke \& Warwick 1994). For each time of sampling, we also identified the taxa best discriminating between these treatments by calculating ratios of mean Bray-Curtis dissimilarity over the SD of dissimilarity. A taxon may be considered a good discriminator when this ratio is $>1.3$ (Clarke \& Warwick 1994).

To ascertain whether any 1 disturbance event was driving differences between the high- and lowfrequency addition treatments, evident at the conclusion of the experiment in Week 24, we performed an additional ANOVA, with the factors intensity of disturbance (fixed: high, low) and timing of detrital addition (fixed: Week 0, 8, 16, all 3 dates). This analysis included Week 24 data from 8 of the experimental treatments in Table 1: HF/HI, HF/LI, LF/HI, LF/LI, HI Control 1, LI Control 1, HI Control 2 and LI Control 2 (HF: high frequency; LF: low frequency).

Relationships between macroinvertebrate assemblage structure and sediment C:N composition, concentration of chl $a$ and seagrass biomass were tested using RELATE (Clarke \& Warwick 1994), part of the PRIMER routine.

\section{RESULTS}

Invertebrate assemblages at Towra Point were highly diverse. In our 2-factor experiment, we collected 2887 animals representing 79 different species. Of these, polychaetes were the most numerous group, with the 28 species found comprising $66 \%$ of the total animals collected. The next most important groups were gastropods (12 species representing $6 \%$ of total abundance), bivalves (7 spp., $5 \%$ ) and amphipods (13 spp., 3\%). Decapods (4 spp., 3\%), nemerteans (3 spp., $2 \%$ ) and oligochaetes (1 spp., <1\%) were less important contributors.

Our experimental additions of Zostera capricornii to sediment plots provided strong evidence for an effect of the frequency of detrital enrichment on the structure of macroinvertebrate assemblages (PERMANOVA, time $\times$ frequency interaction; $F_{2,72}=2.21, \mathrm{p}=0.004$ ). In Weeks 16 and 24 after initiation of experimental disturbance regimes, macroinvertebrate assemblages differed between plots disturbed only once and plots

Table 1. ANOVAs comparing variation in the abundance, species richness and evenness (Pielou's $J^{\prime}$ ) of macrobenthic fauna among treatments exposed to differing intensities and frequencies of detrital enrichment. Ti: time $(3$ levels: Week 8, 16, 24); Fr: frequency of disturbance (2 levels: high [HF], low [LF]); In: intensity of disturbance (2 levels: high [HI], low [LI]); Res: residual. Terms significant at $\alpha=0.05$ are highlighted in bold. All data were $\ln (x+1)$ transformed prior to analysis; $\mathrm{n}=7$. SNK: StudentNewman-Keuls

\begin{tabular}{|c|c|c|c|c|c|c|c|c|c|c|}
\hline \multirow[t]{2}{*}{ Source } & \multirow[b]{2}{*}{$\mathrm{df}$} & \multicolumn{3}{|c|}{ Abundance } & \multicolumn{3}{|c|}{ Species richness } & \multicolumn{3}{|c|}{ Evenness (Pielou's $J^{\prime}$ ) } \\
\hline & & MS & $F$ & $\mathrm{p}$ & MS & $F$ & $\mathrm{p}$ & MS & $F$ & $\mathrm{p}$ \\
\hline $\mathrm{Ti}$ & 2 & 3.50 & 13.06 & $<0.001$ & 0.77 & 5.07 & 0.009 & 0.019 & 1.15 & 0.323 \\
\hline Fr & 1 & 4.88 & 18.19 & $<0.001$ & 2.01 & 13.20 & 0.001 & 0.099 & 6.02 & 0.017 \\
\hline In & 1 & 0.41 & 1.52 & 0.223 & 0.35 & 2.28 & 0.136 & 0.023 & 1.37 & 0.246 \\
\hline $\mathrm{Ti} \times \mathrm{Fr}$ & 2 & 1.71 & 6.39 & 0.003 & 0.57 & 3.75 & 0.028 & 0.024 & 1.45 & 0.242 \\
\hline $\mathrm{Ti} \times \mathrm{In}$ & 2 & 0.65 & 2.44 & 0.095 & 0.06 & 0.37 & 0.692 & 0.004 & 0.21 & 0.809 \\
\hline Fr $\times$ In & 1 & 0.05 & 0.18 & 0.676 & 0.02 & 0.12 & 0.730 & 0.007 & 0.42 & 0.519 \\
\hline $\operatorname{Ti} \times \operatorname{Fr} \times \operatorname{In}$ & 2 & 0.33 & 1.26 & 0.290 & 0.05 & 0.30 & 0.740 & 0.027 & 1.67 & 0.195 \\
\hline Res & 72 & 0.27 & & & 0.15 & & & 0.016 & & \\
\hline \multicolumn{2}{|c|}{ Cochran's test } & \multicolumn{3}{|c|}{$C=0.18, \mathrm{p}>0.05$} & \multicolumn{3}{|c|}{$C=0.21, \mathrm{p}>0.05$} & \multicolumn{3}{|c|}{$C=0.23, \mathrm{p}>0.05$} \\
\hline \multicolumn{2}{|l|}{ SNK tests } & \multicolumn{3}{|c|}{$\begin{array}{c}\quad \mathrm{Ti} \times \mathrm{Fr}: \\
\text { Week 8: HF }=\mathrm{LF} \\
\text { Week 16: HF }<\mathrm{LF} \\
\text { Week 24: HF }<\mathrm{LF}\end{array}$} & \multicolumn{3}{|c|}{$\begin{array}{l}\quad \mathrm{Ti} \times \mathrm{Fr}: \\
\text { Week 8: HF }=\mathrm{LF} \\
\text { Week 16: HF }<\mathrm{LF} \\
\text { Week 24: } \mathrm{HF}<\mathrm{LF}\end{array}$} & \multicolumn{3}{|c|}{$\begin{array}{c}\text { Fr: } \\
\mathrm{HF}<\mathrm{LF}\end{array}$} \\
\hline
\end{tabular}




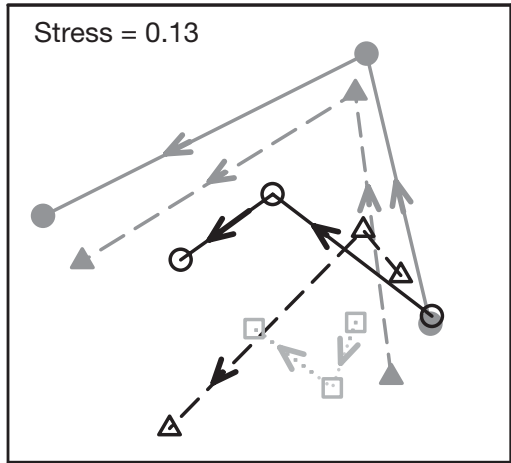

Fig. 2. Non-metric multidimensional scaling ordination tracking change in the average assemblages of macrobenthic invertebrates present within each of the treatments through time, $\mathrm{n}=7$ (grey closed symbols: high frequency of detrital addition; black-bordered open symbols: low frequency of detrital addition; grey-bordered open symbols: no disturbance; circles: high-disturbance intensity; triangles: low-disturbance intensity; squares: no detritus added)

disturbed on multiple occasions, irrespective of whether the plots were enriched with large (high-disturbance intensity, HI) or small (low-disturbance intensity, LI) quantities of detritus (Fig. 2; PERMANOVA a posteriori comparisons, Week 16: HF $\neq$ LF $[p=0.004]$, Week 24: HF $\neq$ LF $[p=0.002])$. These multivariate patterns were due to effects of disturbance frequency on the total abundance, species richness and evenness (Pielou's $J^{\prime}$ ) of macroinvertebrates (Table 1, Fig. 3). After 2 enrichments of the frequently disturbed plots, the abundance and species richness of macroinvertebrates in the frequently disturbed plots was half that in plots disturbed only once and less than one-third of that in undisturbed, control plots. By the conclusion of the experiment, the plots enriched 3 times (HF) contained no more than two-thirds the abundance and species richness of the infrequently disturbed (LF) or undisturbed sediment.

In contrast to the frequency of detrital enrichment, the intensity of the disturbance had only weak effects on macroinvertebrate community structure (Table 1, Fig. 3). Only $24 \mathrm{wk}$ after enrichment did differences between high and low intensities of enrichment become evident, and, even then, these were not statistically significant and were only seen among plots disturbed just once (LF: Table 1, Fig. 3). High abundances of macroinvertebrates in plots subjected to a low intensity of disturbance, in particular the sea hare Aplysia parvula Guilding in Moerch, 1863 and the crab Paragrapsus laevis Dana, 1851, drove this pattern. The species richness and evenness were, however, also slightly greater in the less enriched plots of infrequently disturbed sediment than in the other plots by the end of the experiment (Fig. 3).
No single disturbance event consistently (i.e. across each of the disturbance intensities) drove the 'frequency effect' identified in the 2-factor analyses (ANOVA, $p<0.05$ Intensity $\times$ Time of addition interaction). Although, at the conclusion of the experiment, plots disturbed once with a small quantity of detritus contained less macroinvertebrates when the disturbance was in Week $8\left(17 \pm 6\right.$ core $\left.^{-1}\right)$ than when it was in Week $0\left(45 \pm 14\right.$ core $\left.^{-1}\right)$ or $16\left(64 \pm 17\right.$ core $^{-1}$; SNK, $\mathrm{p}<0.05)$, among treatments receiving a single addition of the larger detrital quantity, macroinvertebrate abundance was independent of the time of detrital addition (ANOVA, $p>0.05$ ). Among plots receiving a low intensity of disturbance, the single Week 8 disturbance did not reduce abundances by as much as the application of 3 small detrital additions to a plot (final abundances
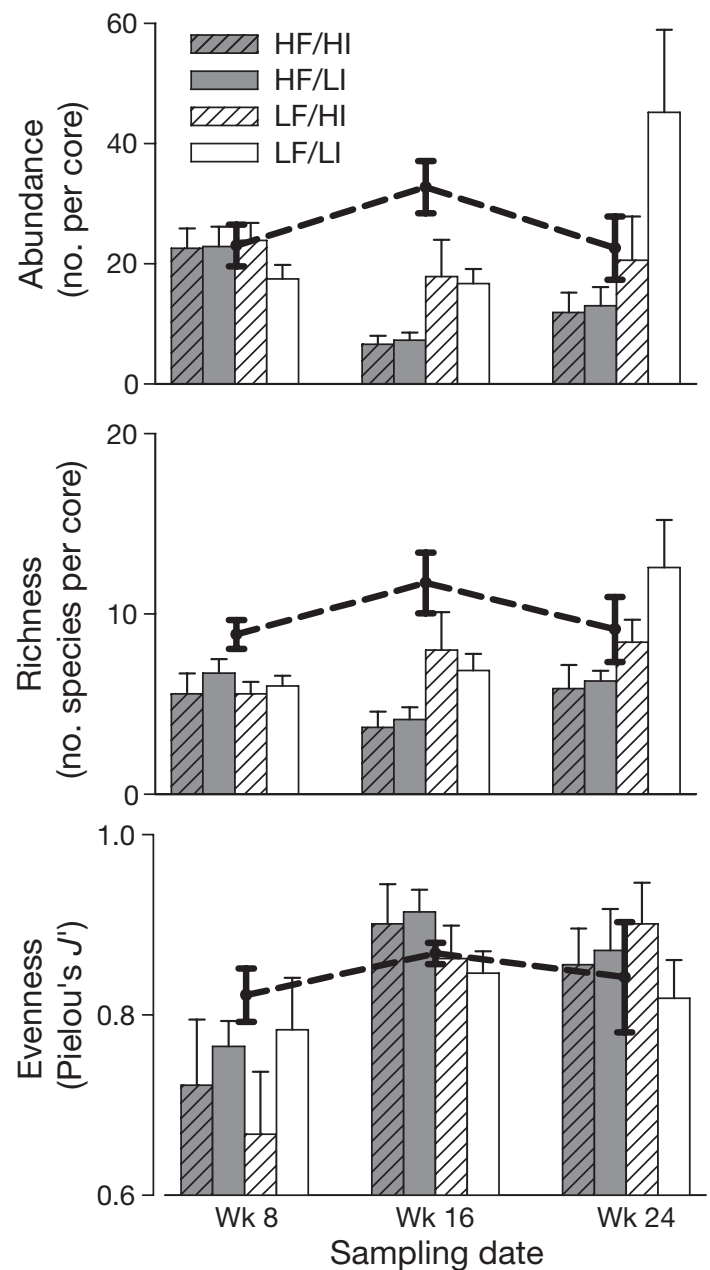

Fig. 3. Mean (+1 SE) abundance, species richness and evenness (Pielou's $J^{\prime}$ ) of macroinvertebrates in experimental treatments where frequency (HF: high; LF: low) and intensity (HI: high; LI: low) of detrital addition were manipulated. The superimposed line graph indicates change in abundance, species richness or evenness (as appropriate) of macroinvertebrates in undisturbed sediment over experimental period, $\mathrm{n}=7$ 
$17 \pm 6$ vs. $13 \pm 3$ core $^{-1} ;$ SNK, $\left.p<0.05\right)$. Thus, the frequency effect could not be explained by the Week 8 disturbance alone.

SIMPER analysis indicated 7 taxa to be driving multivariate responses of benthic invertebrate assemblages to the frequency of detrital disturbance (Table 2). The nephytid Nephtys australiensis Fauchald, 1965; the capitellid Mediomastus australiensis Warren, Hutchings \& Doyle, 1994; the capitellid Heteromastus filiformis Claparéde, 1864; the ophelid Armandia sp.; the owenid Owenia australis Evans \& Hutchings, 2005; the sea hare Aplysia parvula; and the crab Paragrapsus laevis together accounted for $>50 \%$ of the dissimilarity between treatments with low or high frequency of detrital addition (Table 2). Of these taxa, all but $H$. filiformis were reduced in abundance by multiple disturbances. H. filiformis, by contrast, displayed $42 \%$ greater abundance in the frequently disturbed treatments by the end of the experiment.

Both the frequency and intensity of disturbance affected the C:N ratio of the sediment (Table 3, Fig. 4). These effects were, however, highly dependent on the timing of sampling relative to detrital additions. Whereas $8 \mathrm{wk}$ into the experiment, plots receiving a large quantity of detritus contained a greater $\mathrm{C}: \mathrm{N}$ ratio than plots receiving a small quantity, this pattern had disappeared by Week 16 (Table 3, Fig. 4), perhaps due to the uptake of initially whole detritus by organisms. In Week 16, plots that had received detritus on 2 occasions had a higher $\mathrm{C}: \mathrm{N}$ ratio than plots receiving a single detrital addition, a pattern that did not persist to Week 24, by which time 'high-intensity' plots had received a third detrital addition (Table 3, Fig. 4). The enhanced C:N ratio in Week 8 of plots receiving a large quantity of detritus was driven by a decrease in the percent nitrogen. In Week 16, percent nitrogen also appeared to be greater in the frequently disturbed plots with a high C:N ratio, although this pattern was not statistically significant (Table 3, Fig. 4). Percent carbon did not differ appreciably among treatments at any of the 3 times of sampling (Table 3, Fig. 4). Across the 3 times of sampling, C:N ratios bore no relationship to macroinvertebrate assemblage structure (RELATE: $\rho_{\mathrm{s}}=-0.056, \mathrm{p}=0.92$ ).

In contrast to $\mathrm{C}: \mathrm{N}$ ratios, the total dry weights of Zostera capricornii and Halophila ovalis shoots displayed similar responses to detrital addition as macroinvertebrate assemblage structure, being more influenced by disturbance frequency than intensity. Irrespective of the volume of detritus added, disturbance reduced the biomass of $Z$. capricornii and $H$. ovalis shoots well below ambient levels (Table 4, Fig. 5). Whereas some recovery of seagrass shoots was seen in the plots disturbed only once, in plots disturbed multiple times, biomasses remained depressed for the duration of the experiment. The degree to which seagrass biomasses were depressed was, however, also determined by disturbance intensity. Plots receiving the larger dosage of detritus experienced greater declines in $Z$. capricornii and $H$. ovalis shoot biomass

Table 2. Results of SIMPER analyses showing taxa that cumulatively accounted for $>50 \%$ of dissimilarity between high (HF) and low (LF) frequencies of addition at each of the 3 times of sampling. Data are mean $( \pm \mathrm{SE})$ numbers of individuals per core, averaged across the 14 cores treatment ${ }^{-1}$. Numbers in bold: \% dissimilarity between groups of the best discriminating taxa, i.e. those with ratios of dissimilarity over $\mathrm{SD} \geq 1.3$ (see 'Materials and methods')

\begin{tabular}{|c|c|c|c|c|c|c|c|c|c|}
\hline \multirow[t]{3}{*}{ Taxon } & \multicolumn{3}{|c|}{ Week 8} & \multicolumn{3}{|c|}{ Week 16} & \multicolumn{3}{|c|}{ Week 24} \\
\hline & \multicolumn{2}{|c|}{ Mean no. } & \multirow{2}{*}{$\begin{array}{c}\text { Dissim. } \\
(\%)\end{array}$} & \multicolumn{2}{|c|}{ Mean no. } & \multirow{2}{*}{$\begin{array}{l}\text { Dissim. } \\
(\%)\end{array}$} & \multicolumn{2}{|c|}{ Mean no. } & \multirow{2}{*}{$\begin{array}{c}\text { Dissim. } \\
(\%)\end{array}$} \\
\hline & & & & $\mathrm{HF}$ & & & $\mathrm{HF}$ & & \\
\hline Nephtys australiensis & $\begin{array}{l}12.64 \\
(1.83)\end{array}$ & $\begin{array}{l}11.50 \\
(1.83)\end{array}$ & 32.32 & $\begin{array}{c}1.21 \\
(0.49)\end{array}$ & $\begin{array}{c}3.79 \\
(1.07)\end{array}$ & 20.93 & $\begin{array}{c}2.29 \\
(0.73)\end{array}$ & $\begin{array}{c}3.86 \\
(0.81)\end{array}$ & 12.40 \\
\hline Mediomastus australiensis & $\begin{array}{r}2.14 \\
(0.64)\end{array}$ & $\begin{array}{r}4.29 \\
(0.57)\end{array}$ & 14.92 & $\begin{array}{c}2.50 \\
(0.43)\end{array}$ & $\begin{array}{c}3.79 \\
(0.88)\end{array}$ & 16.91 & $\begin{array}{c}0.21 \\
(0.12)\end{array}$ & $\begin{array}{c}2.79 \\
(0.80)\end{array}$ & 8.38 \\
\hline Heteromastus filiformis & $\begin{array}{c}2.00 \\
(0.69)\end{array}$ & $\begin{array}{c}0.36 \\
(0.37)\end{array}$ & 10.61 & & & & $\begin{array}{c}2.43 \\
(0.43)\end{array}$ & $\begin{array}{c}1.71 \\
(0.74)\end{array}$ & 9.54 \\
\hline Armandia sp. & & & & $\begin{array}{c}0.64 \\
(0.23)\end{array}$ & $\begin{array}{c}1.79 \\
(0.57)\end{array}$ & 10.54 & & & \\
\hline Owenia australis & & & & $\begin{array}{c}0.14 \\
(0.10)\end{array}$ & $\begin{array}{c}1.07 \\
(0.43)\end{array}$ & 5.70 & & & \\
\hline Aplysia parvula & & & & & & & $\begin{array}{c}2.71 \\
(1.48)\end{array}$ & $\begin{array}{c}9.64 \\
(4.79)\end{array}$ & 19.41 \\
\hline Paragrapsus laevis & & & & & & & $\begin{array}{c}0.57 \\
(0.14)\end{array}$ & $\begin{array}{c}1.79 \\
(0.52)\end{array}$ & 4.26 \\
\hline Average dissimilarity & & 49.58 & & & 73.95 & & & 80.10 & \\
\hline
\end{tabular}


Table 3. ANOVAs comparing variation in sediment $\mathrm{C}: \mathrm{N}$ ratio, percent $\mathrm{C}$ and percent $\mathrm{N}$ among treatments exposed to differing intensities and frequencies of detrital enrichment. Ti: time (3 levels: Weeks 8, 16, 24); Fr: frequency of disturbance (2 levels: high $[\mathrm{HF}]$, low [LF]); In: intensity of disturbance (2 levels: high [HI], low [LI]); Res: residual. Terms significant at $\alpha=0.05$ are highlighted in bold. C:N ratios were $\ln (x+1)$ transformed and percent $\mathrm{C}$ and percent $\mathrm{N}$ values arcsine $(\%)$ transformed prior to analysis, $\mathrm{n}=7$

\begin{tabular}{|c|c|c|c|c|c|c|c|c|c|c|}
\hline \multirow[t]{2}{*}{ Source } & \multirow[b]{2}{*}{ df } & \multicolumn{3}{|c|}{$\mathrm{C}: \mathrm{N}$ ratio } & \multicolumn{3}{|c|}{$\% \mathrm{C}$} & \multicolumn{3}{|c|}{$\% \mathrm{~N}$} \\
\hline & & MS & $F$ & $\mathrm{p}$ & MS & $F$ & $\mathrm{p}$ & MS & $F$ & $\mathrm{p}$ \\
\hline $\mathrm{Ti}$ & 2 & 0.266 & 7.73 & 0.001 & 0.066 & 0.51 & 0.602 & 0.102 & 3.76 & 0.028 \\
\hline Fr & 1 & 0.007 & 0.21 & 0.648 & 0.031 & 0.24 & 0.627 & 0.001 & 0.03 & 0.871 \\
\hline In & 1 & 0.043 & 1.24 & 0.270 & 0.066 & 0.51 & 0.477 & 0.024 & 0.87 & 0.354 \\
\hline $\mathrm{Ti} \times \mathrm{Fr}$ & 2 & 0.129 & 3.74 & 0.028 & 0.039 & 0.30 & 0.739 & 0.027 & 1.01 & 0.368 \\
\hline $\mathrm{Ti} \times \operatorname{In}$ & 2 & 0.111 & 3.23 & 0.046 & 0.188 & 1.45 & 0.242 & 0.085 & 3.14 & 0.050 \\
\hline Fr $\times$ In & 1 & 0.004 & 0.12 & 0.726 & 0.075 & 0.58 & 0.449 & 0.007 & 0.25 & 0.619 \\
\hline $\operatorname{Ti} \times$ Fr $\times$ In & 2 & 0.017 & 0.49 & 0.616 & 0.197 & 1.52 & 0.226 & 0.030 & 1.11 & 0.336 \\
\hline Res & 72 & 0.034 & & & 0.130 & & & 0.027 & & \\
\hline \multicolumn{2}{|c|}{ Cochran's test } & \multicolumn{3}{|c|}{$C=0.26, \mathrm{p}<0.05$} & \multicolumn{3}{|c|}{$C=0.16, \mathrm{p}>0.05$} & \multicolumn{3}{|c|}{$C=0.17, \mathrm{p}>0.05$} \\
\hline \multirow[t]{2}{*}{ SNK tests } & & \multicolumn{3}{|c|}{$\begin{array}{c}\mathrm{Ti} \times \mathrm{Fr}: \\
\text { Week 8: HF }=\mathrm{LF} \\
\text { Week 16: HF }>\mathrm{LF} \\
\text { Week 24: HF }=\mathrm{LF}\end{array}$} & & & & \multicolumn{3}{|c|}{$\begin{array}{c}\text { Ti } \times \text { In: } \\
\text { Week 8: HD < LD } \\
\text { Week 16: HD = LD } \\
\text { Week 24: HD }=\mathrm{LD}\end{array}$} \\
\hline & & \multicolumn{3}{|c|}{$\begin{array}{c}\text { Ti } \times \text { In: } \\
\text { Week 8: HD > LD } \\
\text { Week 16: HD = LD } \\
\text { Week 24: HD = LD }\end{array}$} & & & & & & \\
\hline
\end{tabular}

Table 4. ANOVAs comparing variation in the dry weight of Halophila ovalis and Zostera capricornii shoots and total seagrass roots among treatments exposed to differing intensities and frequencies of detrital enrichment. (Ti: time [3 levels: Week 8, 16, 24]; Fr: frequency of disturbance (2 levels: high $[\mathrm{HF}]$, low [LF]); In: intensity of disturbance (2 levels: high [HI], low [LI]); Res: residual. Terms significant at $\alpha=0.05$ are highlighted in bold, $\mathrm{n}=7$

\begin{tabular}{|c|c|c|c|c|c|c|c|c|c|c|}
\hline \multirow[t]{2}{*}{ Source } & \multirow[b]{2}{*}{$\mathrm{df}$} & \multicolumn{3}{|c|}{ Halophila ovalis } & \multicolumn{3}{|c|}{ Zostera capricornii } & \multicolumn{3}{|c|}{ Roots } \\
\hline & & MS & $F$ & $\mathrm{p}$ & MS & $F$ & $\mathrm{p}$ & MS & $F$ & $\mathrm{p}$ \\
\hline $\mathrm{Ti}$ & 2 & 0.005 & 2.57 & 0.084 & 0.000 & 0.12 & 0.891 & 0.293 & 4.72 & 0.012 \\
\hline Fr & 1 & 0.031 & 15.87 & $<0.001$ & 0.033 & 19.92 & $<0.001$ & 0.926 & 14.92 & $<0.001$ \\
\hline In & 1 & 0.009 & 4.68 & 0.034 & 0.010 & 6.16 & 0.015 & 0.063 & 1.02 & 0.316 \\
\hline $\mathrm{Ti} \times \mathrm{Fr}$ & 2 & 0.008 & 4.20 & 0.019 & 0.006 & 3.80 & 0.027 & 0.102 & 1.64 & 0.202 \\
\hline $\mathrm{Ti} \times \mathrm{In}$ & 2 & 0.005 & 2.56 & 0.084 & 0.001 & 0.49 & 0.612 & 0.064 & 1.03 & 0.361 \\
\hline Fr $\times$ In & 1 & 0.006 & 2.89 & 0.095 & 0.001 & 0.44 & 0.512 & 0.115 & 1.85 & 0.178 \\
\hline $\mathrm{Ti} \times \mathrm{Fr} \times \mathrm{In}$ & 2 & 0.005 & 2.64 & 0.078 & 0.000 & 0.00 & 0.997 & 0.126 & 2.03 & 0.139 \\
\hline Res & 72 & 0.002 & & & 0.002 & & & 0.062 & & \\
\hline \multicolumn{2}{|c|}{ Cochran's test } & \multicolumn{3}{|c|}{$C=0.62, \mathrm{p}<0.01$} & \multicolumn{3}{|c|}{$C=0.22, \mathrm{p}>0.05$} & \multicolumn{3}{|c|}{$C=0.40, \mathrm{p}<0.01$} \\
\hline \multicolumn{2}{|l|}{ SNK tests } & \multicolumn{3}{|c|}{$\begin{array}{c}\mathrm{Ti} \times \mathrm{Fr}: \\
\text { Week 8: HF }=\mathrm{LF} \\
\text { Week 16: HF }<\mathrm{LF} \\
\text { Week 24: HF }<\mathrm{LF} \\
\text { In: } \\
\mathrm{HI}<\mathrm{LI}\end{array}$} & \multicolumn{3}{|c|}{$\begin{array}{c}\mathrm{Ti} \times \mathrm{Fr}: \\
\text { Week 8: HF }=\mathrm{LF} \\
\text { Week 16: HF }<\mathrm{LF} \\
\text { Week 24: } \mathrm{HF}<\mathrm{LF} \\
\text { In: } \\
\text { HI }<\mathrm{LI}\end{array}$} & \multicolumn{3}{|c|}{$\begin{array}{c}\text { Fr: } \\
\text { HF < LF } \\
\text { Ti: } \\
\text { Week } 8=\mathrm{W}\end{array}$} \\
\hline
\end{tabular}

than plots receiving the smaller amount (Table 4, Fig. 5). Of the 2 seagrasses, $H$. ovalis was the more resilient species, recovering to ambient biomass by Week 16 if left undisturbed. Recovery of $Z$. capricornii to ambient levels, by contrast, was only seen after $24 \mathrm{wk}$, and only in the plots where the initial disturbance was of low intensity. In plots where the initial disturbance was of high intensity, the biomass of $Z$. capricornii shoots remained $<50 \%$ of ambient levels for the duration of the experiment. The biomass of seagrass roots was only reduced below ambient levels in plots experiencing $>1$ disturbance event (Table 4, Fig. 5). Despite the seemingly concordant patterns in seagrass biomass and macroinvertebrate assemblage structure, neither the shoot biomass of $H$. ovalis nor $Z$. capricornii was significantly correlated with macroinvertebrate assemblage structure (RELATE: $H$. ovalis $\rho_{\mathrm{s}}=0.026, \mathrm{p}=0.33 ; Z$. capricornii $\rho_{\mathrm{s}}=-0.011, \mathrm{p}=0.57$ ). 

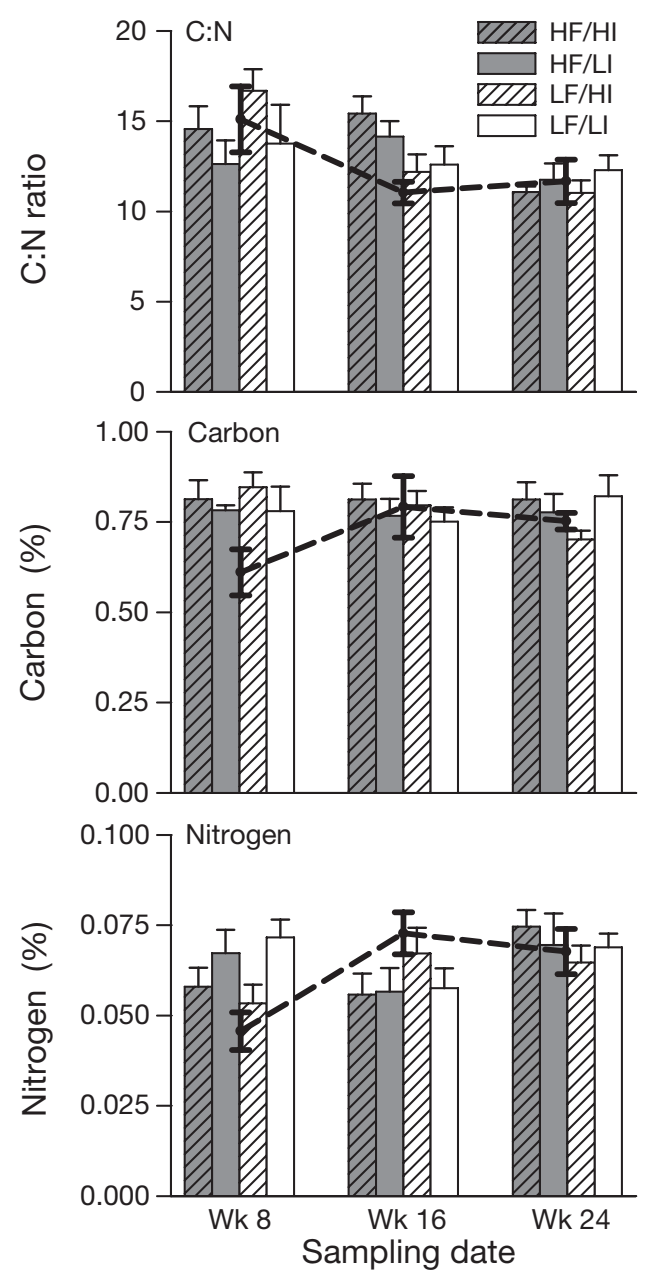

Fig. 4. Mean (+1 SE) carbon to nitrogen ratio $(\mathrm{C}: \mathrm{N})$, percent carbon content and percent nitrogen content of sediments in experimental plots where frequency (HF: high; LF: low) and intensity (HI: high; LI: low) of detrital addition were manipulated. The superimposed line graph indicates change in $\mathrm{C}: \mathrm{N}$ ratio, percent carbon or percent nitrogen (as appropriate) in undisturbed sediment over the experimental period, $\mathrm{n}=7$

Whereas the abundance of macroinvertebrates appeared to be driven most by disturbance frequency, microphytobenthic biomass was more closely linked to the amount of detritus added to plots than the number of times it was added. Across all 3 times of sampling, the concentration of chl $a$, an indicator of microphytobenthic biomass, was greater in treatments exposed to high intensities of the disturbance than treatments exposed to low intensities (Table 5, Fig. 6). The frequency of the disturbance, by contrast, only appeared to influence the abundance of microphytobenthos in Week 16, by which time treatments of high-disturbance frequency had been enriched twice (Table 5, Fig. 6). A greater abundance of microphytobenthos was found in plots enriched twice than in plots
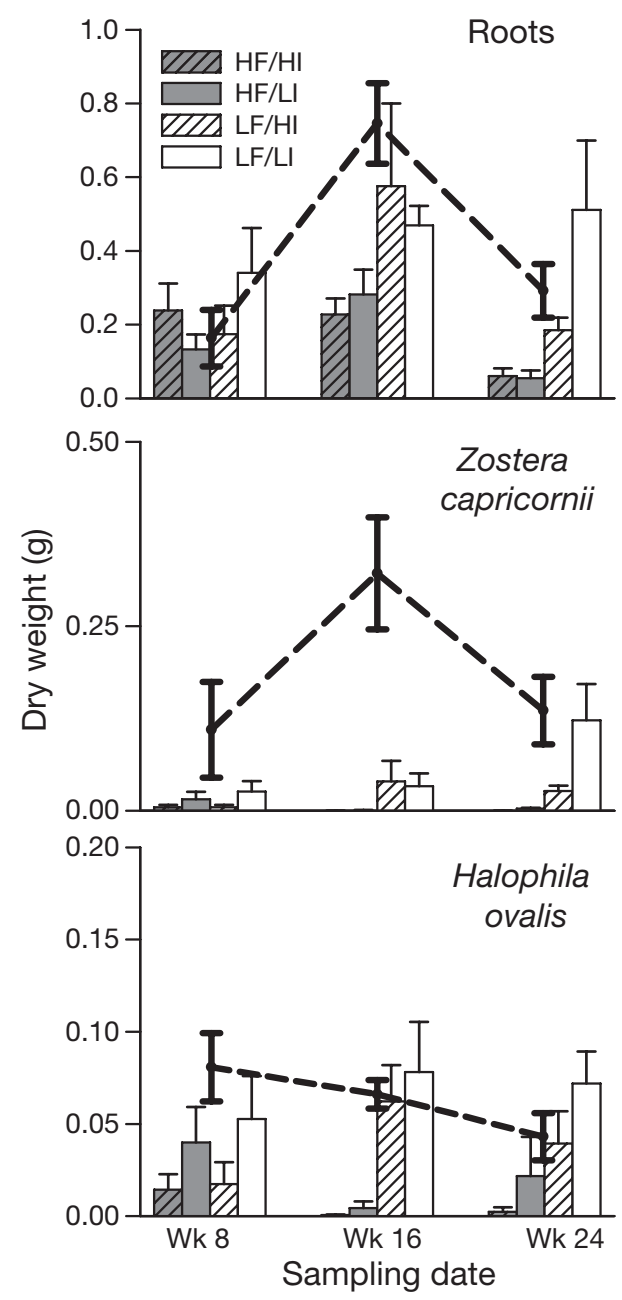

Fig. 5. Zostera capricornii, Halophila ovalis. Mean (+1 SE) dry weight of shoots and total root biomass in experimental plots where frequency (HF: high; LF: low) and intensity (HI: high; LI: low) of detrital addition were manipulated. The superimposed line graph indicates change in the dry weights of seagrass roots or shoots (as appropriate) in undisturbed sediment over the experimental period, $\mathrm{n}=7$

enriched once, irrespective of the amount of detritus added (Table 5). As anticipated from the significant effect of disturbance intensity on concentration of chl $a$, chl a was weakly correlated with the C:N ratio (RELATE: $\rho_{\mathrm{s}}=0.034, \mathrm{p}=0.18$ ). Not surprisingly, given the different factors driving macroinvertebrate assemblage structure and concentration of chl $a$, these 2 variables were not related (RELATE: $\rho_{\mathrm{s}}=-0.041, \mathrm{p}=0.79$ ).

\section{DISCUSSION}

Across the frequencies and intensities tested by our study, the number of occasions on which Zostera capricornii was added to plots was a much better determi- 
Table 5. ANOVAs comparing variation in the concentration of chl $a$ among treatments exposed to differing intensities and frequencies of detrital enrichment. Ti: time (3 levels: Week 8, $16,24)_{i}$ Fr: frequency of disturbance (2 levels: high [HF], low [LF]); In: intensity of disturbance (2 levels: high [HI], low [LI]); Res: residual. Terms significant at $\alpha=0.05$ are high-lighted in bold, $\mathrm{n}=7$

\begin{tabular}{|c|c|c|c|c|}
\hline Source & $\mathrm{df}$ & MS & $F$ & $\mathrm{p}$ \\
\hline $\mathrm{Ti}$ & 2 & 5.21 & 2.89 & 0.062 \\
\hline Fr & 1 & 1.72 & 0.95 & 0.333 \\
\hline In & 1 & 14.09 & 7.80 & 0.007 \\
\hline $\mathrm{Ti} \times \mathrm{Fr}$ & 2 & 6.27 & 3.47 & 0.036 \\
\hline $\mathrm{Ti} \times \mathrm{In}$ & 2 & 1.17 & 0.65 & 0.526 \\
\hline Fr $\times$ In & 1 & 0.79 & 0.44 & 0.509 \\
\hline $\mathrm{Ti} \times \mathrm{Fr} \times \mathrm{In}$ & 2 & 1.62 & 0.89 & 0.413 \\
\hline Res & 72 & 1.81 & & \\
\hline \multicolumn{2}{|c|}{ Cochran's test } & \multicolumn{3}{|c|}{$C=0.17, \mathrm{p}>0.05$} \\
\hline \multicolumn{2}{|l|}{ SNK tests } & \multicolumn{3}{|c|}{$\begin{array}{c}\mathrm{Ti} \times \mathrm{Fr}: \\
\text { Week 8: HF }=\mathrm{LF} \\
\text { Week 16: HF }>\mathrm{LF} \\
\text { Week 24: HF }=\mathrm{LF} \\
\text { In: } \\
\mathrm{HI}>\mathrm{LI}\end{array}$} \\
\hline
\end{tabular}

nant of macroinvertebrate assemblage structure than the overall amount of detritus added. While disturbance of plots at high frequency reduced the abundance of their macroinvertebrates and the species richness and evenness of their assemblages below levels found in undisturbed plots and plots disturbed only once, only in plots disturbed at low frequency did intensity of the disturbance affect assemblage structure. In the plots disturbed at low frequency, reduction of macroinvertebrate abundance with increasing detrital enrichment was evident 5 mo after initial disturbance. At high frequencies of detrital addition, plots to which small and large quantities of detritus were added contained similar assemblages of macroinvertebrates, irrespective of the time after disturbance at which they were sampled. This was despite the final biomass of detritus added being 3 times greater in the high- than the low-disturbance intensity treatment.

Our finding that the amount of detritus added to plots was relatively unimportant in determining the impact on macroinvertebrate assemblages contradicts results of previous studies. Lee (1999) found that species richness, Shannon diversity and evenness, as well as the total number of macroinvertebrates, were generally lower in plots receiving high than in those receiving low quantities of Kandelia candel mangrove leaf detritus. Studies in freshwater streams report positive correlations between invertebrate abundance and the availability of particulate organic matter (e.g. Wallace et al. 1999, González \& Graça 2005). A growing body of literature suggests that the background nutri- ent loading of a system is important in determining its response to enrichment (e.g. Rossi \& Underwood 2002, Posey et al. 2006). Many aquatic systems display nonlinear responses to organic enrichment (Pearson \& Rosenberg 1978), such that the magnitude and indeed even the directionality of an impact is dependent on the natural background loading of the system. Though few studies have reported starting nutrient loads of their experimentally perturbed systems, the Towra Point mudflat which is proximal to a sizeable mangrove forest and Posidonia australis and Zostera capricornii seagrass beds, is likely to represent a relatively organic-matter-replete system. Thus, one explanation for the absence of an effect of detrital intensity, despite the frequency effect, is that the threshold above which deleterious impacts of enrichment occur was crossed with even the low detritus addition, although past studies conducted in the detritus-rich tropical mangroves of north-east Australia suggest that detritus levels in those systems still influence the abundance of small benthic invertebrates (Alongi 1987, 1990). Indeed, we observed mats of white bacteria, indicative of anaerobic decomposition and over-enrichment on the surface of plots frequently disturbed with large and small quantities of detritus alike. Had this study been done on a mudflat spatially removed from major detrital sources, it is possible that an effect of disturbance intensity may have been seen.

Whereas the abundance of macroinvertebrates appeared to be primarily determined by frequency of the detrital disturbance, microphytobenthic biomass was more closely linked to the amount of detritus added to plots. Across both frequency treatments and all sampling times, microphytobenthic biomass was greater in plots subject to the high- than to the lowdisturbance intensity. The failure of macroinverte-

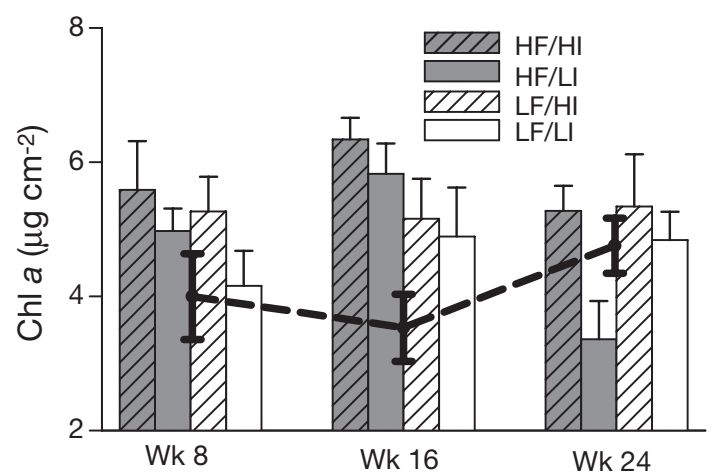

Fig. 6. Mean (+1 SE) chl a concentration within experimental plots where frequency (HF: high; LF: low) and intensity (HI: high; LI: low) of detrital addition were manipulated. The superimposed line graph indicates change in the chl a concentration in undisturbed sediment over the experimental period, $\mathrm{n}=7$ 
brates to respond to disturbance intensity, despite its large positive effect on microphytobenthic biomass, is counterintuitive given that the microphytobenthos is a major food source of the deposit-feeders that dominate mud-flat assemblages (Findlay \& Tenore 1982, Lopez \& Levinton 1987). Although we did not quantify changes in the oxidation-reduction condition of the sediment or microbial metabolic processes, one explanation for the uncoupling of the 2 food web components is that the microbial processes stimulated by detrital addition significantly reduced the oxic layer, affecting deepdwelling macroinvertebrates, but not the surfacedwelling microphytobenthos that could still take advantage of enhanced resource availability. This hypothesis that initial anoxia of sediments prevented macroinvertebrates from capitalising on resources is supported by the observation of a delayed effect of manipulating detrital intensity, first seen 5 mo after a single detrital disturbance.

Our study design did not attempt to separate physical and chemical effects of detrital addition. During storms, the top few centimetres of the sediment are naturally mixed by wind and waves (e.g. Bell et al. 1997). Indeed, without this physical disturbance of the sediment to bury organic matter, it is doubtful whether prolonged detrital enrichment of sediments could even occur. Even though previous sampling at Quibray Bay $(6.3 \mathrm{~cm}$ cores sieved through a $500 \mu \mathrm{m}$ mesh) suggested that hand churning of detritus into plots 1 time only has minimal, if any, affect on benthic macroinvertebrate assemblages (Bishop et al. 2007), 3 lines of evidence suggest that in the present study detrital impacts on invertebrates-which increased with disturbance frequency - were, at least in part, attributable to physical disturbance. First, hand churning of the sediment uprooted the seasonally abundant seagrasses Zostera capricornii and Halophila ovalis, initially profuse within our experimental plots. The abundances and diversities of many faunal groups, including clams, amphipods and polychaetes, are well known to be enhanced by the structure of even sparse seagrass (Orth et al. 1984). Where detrital enrichment was frequent, reduced biomasses of seagrasses were sustained for the duration of the experiment. Second, tube-dwelling species, such as Owenia australis, presumably very susceptible to physical disturbance, displayed highly depressed abundances in all manipulated plots relative to undisturbed controls. Finally, whereas increased abundances of macroinvertebrates in plots receiving high detrital loadings would be expected if resource availability were driving patterns, impacts on macroinvertebrates were negative. This was true despite generally positive effects of the disturbance on microphytobenthic biomass.
Although several previous studies suggest that negative impacts of detrital enrichment on macroinvertebrate assemblages can be mediated by the attraction of dominant consumers to resource-rich areas (e.g. Flecker 1996, Kelaher et al. 2003), this does not appear to be the case here. In previous experiments at our study site, macroinvertebrate assemblages did not differ between plots open to or closed to large mobile species, such as crabs, fish and rays, irrespective of whether the plots were organically enriched or not (Bishop et al. 2007). While the large detritivorous gastropod Pyrazus ebeninus, recently identified as a trophic cul-de-sac in this system (Bishop et al. 2007), could potentially play a role in depressing macroinvertebrate abundances in areas of high resource availability, sampling of surface densities of this gastropod in experimental plots at 8,16 and 24 wk provided no evidence that the snail is attracted to areas of high resource availability (M. J. Bishop unpubl. data).

Our results have important implications for the conservation of globally important benthic systems under the threat of climate warming. If, as predicted, climate warming results in more frequent storms, the concomitant increase in the frequency of detrital enrichment may strongly reduce the abundance and diversity of macroinvertebrates in shallow estuarine and marine habitats that are seasonally covered by seagrass. Because the impacts of detrital enrichment in such environments are primarily determined by the frequency and not the intensity of disturbance, even frequent disturbances that result in smaller standing stocks of aquatic macrophytes will cause deleterious impacts on macroinvertebrates. This is of concern given the critical importance of macroinvertebrates in global nutrient cycling, the fuelling of fisheries production and stabilising the sediment (Snelgrove 1999). Clearly, long-term monitoring programmes and largescale management experiments are needed to ascertain whether the effects of climate change on macroinvertebrates that we posit are indeed occurring. Nevertheless, by providing a better mechanistic understanding of how detrital enrichment influences the composition of macroinvertebrate assemblages, we can increase our ability to predict the possible consequences of a continued warming for the diversity and productivity of important coastal ecosystems.

Acknowledgements. This study was funded by an Australian Research Council Discovery Grant to B.P.K. and a University of Technology Sydney Early Career Researcher Grant to M.J.B., M. Cole, M. Verhoeven and S. Taylor assisted with the collection and processing of detritus for experimental additions, field sampling and the laboratory processing of sediment cores. The thoughtful comments of 3 anonymous reviewers improved the quality of this manuscript. 


\section{LITERATURE CITED}

Alongi DM (1987) Inter-estuary variation and intertidal zonation of free-living nematode communities in tropical mangrove systems. Mar Ecol Prog Ser 40:103-114

Alongi DM (1990) Abundances of benthic microfauna in relation to outwelling of mangrove detritus in a tropical coastal region. Mar Ecol Prog Ser 63:53-63

Anderson MJ (2001) A new method for non-parametric multivariate analysis of variance. Austral Ecol 26:32-46

Bell RG, Hume TM, Dolphin TJ, Green MO, Walters RA (1997) Characterization of physical environmental factors on an intertidal sandflat, Manukau Harbour, New Zealand. J Exp Mar Biol Ecol 216:11-31

Benedetti-Cecchi L (2003) The importance of variance around the mean effect size of ecological processes. Ecology 84: 2335-2346

Bishop MJ, Kelaher BP, Alquezar R, York PH, Ralph PJ, Skilbeck CG (2007) Trophic cul-de-sac, Pyrazus ebeninus, limits trophic transfer through an estuarine detritus-based food web. Oikos 116:427-438

Bray JR, Curtis JT (1957) An ordination of the upland forest communities of southern Wisconsin. Ecol Monogr 27: 325-349

Clarke KR, Warwick RM (1994) Change in marine communities: an approach to statistical analysis and interpretation, 2nd edn. PRIMER-E, Plymouth

Connell JH (1978) Diversity in tropical rain-forests and coral reefs. Science 199:1302-1310

Cummins SP, Roberts DE, Zimmerman KD (2004) Effects of the green macroalga Enteromorpha intestinalis on macrobenthic and seagrass assemblages in a shallow coastal estuary. Mar Ecol Prog Ser 266:77-87

Dennison WC, Orth RJ, Moore KA, Stevenson JC, Carter V, Kollar S, Bergstrom PW, Batiuk RA (1993) Assessing water-quality with submersed aquatic vegetation. BioScience 43:86-94

Diaz RM, Yap HT (1999) Short-term responses of coral reef microphytobenthic communities to inorganic nutrient loading. Limnol Oceanogr 44:1259-1267

Field JG, Clarke KR, Warwick RM (1982) A practical strategy for analysing multispecies distribution patterns. Mar Ecol Prog Ser 8:37-52

Findlay S, Tenore K (1982) Nitrogen source for a detritivore: detritus substrate versus associated microbes. Science 218:371-373

Flecker AS (1996) Ecosystem engineering by a dominant detritivore in a diverse tropical stream. Ecology 77:1845-1854

Gessner MO (1991) Differences in processing dynamics of fresh and dried leaf litter in a stream ecosystem. Freshw Biol 26:387-398

González JM, Graça MAS (2005) Influence of detritus on the structure of the invertebrate community in a small Portuguese stream. Int Rev Hydrobiol 90:534-545

Huston M (1994) Biological diversity: the coexistence of species in changing landscapes. Cambridge University Press, Cambridge

IPCC (Intergovernmental Panel on Climate Change) (2001) Climate Change 2001: impacts, adaptation, and vulnerability. In: McCarthy JJ, Canziani OF, Leary NA, Dokken DJ, White KS (eds) Intergovernmental Panel on Climate Change third assessment report. Cambridge University Press, Cambridge

Jeffrey SW, Humphrey GF (1975) New spectrophotometric equations for determining chlorophylls $a, b, c 1$ and $c 2$ in higher plants, algae, and natural phytoplankton. Biochem Physiol Pflanz 167:191-194
Jernakoff P, Brearley A, Nielsen J (1996) Factors affecting grazer-epiphyte interactions in temperate seagrass meadows. Annu Rev Oceanogr Mar Biol 34:109-162

Junkins R, Kelaher B, Levinton J (2006) Contributions of adult oligochaete emigration and immigration in a dynamic soft sediment community. J Exp Mar Biol Ecol 330:208-220

Kelaher BP, Levinton JS (2003) Variation in detrital enrichment causes spatio-temporal variation in soft-sediment assemblages. Mar Ecol Prog Ser 261:85-97

Lee SY (1999) The effect of mangrove leaf litter enrichment on macrobenthic colonization of defaunated sandy substrates. Estuar Coast Shelf Sci 49:703-712

Lopez GR, Levinton JS (1987) Ecology of deposit-feeding animals in marine-sediments. Q Rev Biol 62:235-260

Michener WK, Blood ER, Bildstein KL, Brinson MM, Gardner LR (1997) Climate change, hurricanes and tropical storms and rising sea level in coastal wetlands. Ecol Appl 7: 770-801

Orth RJ, Heck KL, van Montfrans J (1984) Faunal communities in seagrass beds: a review of the influence of plant structure and prey characteristics on predator-prey relationships. Estuaries 7:339-350

Paerl HW (2006) Assessing and managing nutrient-enhanced eutrophication in estuarine and coastal waters: interactive effects of human and climatic perturbations. Ecol Eng 26: 40-54

Paine RT, Tegner MJ, Johnson EA (1998) Compounded perturbations yield ecological surprises. Ecosystems 1: $535-545$

Pearson TH, Rosenberg R (1978) Macrobenthic succession in relation to organic enrichment and pollution of the marine environment. Oceanogr Mar Biol Annu Rev 16:229-311

Pickett STA, White PS (1985) Patch dynamics: a synthesis. In: Pickett STA, White PS (eds) The ecology of natural disturbance and patch dynamics. Academic Press, New York, p 371-384

Pielou EC (1975) Ecological diversity. John Wiley, New York

Posey MH, Alphin TD, Cahoon L (2006) Benthic community responses to nutrient enrichment and predator exclusion: influence of background nutrient concentrations and interactive effects. J Exp Mar Biol Ecol 330:105-118

Rhoads DC, McCall PL, Yingst JY (1978) Disturbance and production on the estuarine seafloor. Am Sci 66:577-586

Rossi F, Underwood AJ (2002) Small-scale disturbance and increased nutrients as influences on intertidal macrobenthic assemblages: experimental burial of wrack in different intertidal environments. Mar Ecol Prog Ser 241: 29-39

Rublee PA (1982) Seasonal distribution of bacteria in salt marsh sediments in North Carolina. Estuar Coast Shelf Sci 15:67-74

Sala OE, Chapin FS, Armesto JJ, Berlow E and 15 others (2000) Global biodiversity scenarios for the year 2100 . Science 287:1770-1774

Serôdio J, da Silva JM, Catarino F (2001) Use of in vivo chlorophyll a fluorescence to quantify short-term variations in the productive biomass of intertidal microphytobenthos. Mar Ecol Prog Ser 218:45-61

Snelgrove PVR (1999) Getting to the bottom of marine biodiversity: sedimentary habitats. BioScience 49:129-138

Sousa WP (1985) Disturbance and patch dynamics on rocky intertidal shores. In: Pickett STA, White PS (eds) The ecology of natural disturbance and patch dynamics. Academic Press, New York, p 101-124

Wallace JB, Eggert SL, Meyer JL, Webster JR (1999) Effects of resource limitation on a detrital based ecosystem. Ecol Monogr 69:409-442 